\title{
Komparácia ochrany l’udských, občianskych a politických práv občanov v medzivojnovej Československej republike a vojnovej Slovenskej republike
}

\section{Tomáš Čentéš}

Absolvent Fakulty práva, Paneurópska vysoká škola, zamestnaný na Krajskom súde $v$ Nitre

Kontaktni e-mail: tomascentes@gmail.com

Comparison of the Protection of Citizens' Rights in the Inter-war Czechoslovakia and the Wartime Slovak Republic

\begin{abstract}
:
The subject of this article is the constitutional protection of human and civil rights in the Czechoslovak Republic and the Czech-Slovak republic and its comparison with the protection of these rights in wartime Slovak republic for a better understanding of how quickly and dramatically the dehumanization of a part of the population can be carried out despite its validity and effectiveness. Slovak Republic, which was established in 1939, was created by the dissolution of Czech-Slovak Republic. Czechoslovak Republic, as one of the countries which have arisen on the ruins of the former Austria-Hungary Empire, was a modern country, democratic, respecting the main principles of the rule of law and equality of all its citizens before the law of the Republic. The purpose of my short article is to try to explain in a simple way the fact that in the Slovak Republic was created an anti-Jewish legislation, but not as a result of some coincidence and pressure from abroad, but that it was a result of thoughtful and pure rational calculation at the origin of the Slovak Republic, and this calculation was fully reflected in the new Constitution and other legislative adopted in summer 1939 and later.
\end{abstract}

\section{Keywords:}

Czechoslovak Republic; Slovak Republic; constitution; anti-Jewish legislation; human and civil rights

\section{Kl’účové slová:}

Československá republika; Slovenská republika; ústavnost'; protižidovská legislatíva; l’udské a občianske práva

DOI: $10.14712 / 2464689 X .2018 .45$

Príspevok je z vel'kej časti súčast'ou dizertačnej práce autora, ktorú obhájil v mesiaci jún 2018 na Ústave teórie a dejín štátu a práva a spoločenskovedných disciplín Fakulte práva Paneurópskej vysokej školy v Bratislave. 
Mnoho dnešných, najmä mladých l’udí, žije v predstave, že dnes ústavným právom garantované práva a slobody nie je možné stratit' a nie sú nikým a ničím ohrozené, nakol'ko necítia ich bezprostredné ohrozenie. Práve preto je dôležité pripomínat' si prípady z minulosti, ked' l'udia zdiel'ali podobný pocit istoty, ktorý sa vel'mi rýchlo ukázal ako falošný. Za týmto účelom je výbornou možnost'ou porovnat' dve ústavy, z rokov 1920 a 1939 prijaté v krátkom časovom úseku pre jedno územie (slovenské) a pre rovnaké obyvatel'stvo. Ústava Československej republiky, alebo, ak chceme, Ústavní listina Československej republiky, bola prijatá Dočasným Národným Zhromaždením dňa 29. februára 1920 ako ústavný zákon č. 121/1920 Zb. s účinnost'ou od dňa 6. marca 1920. V d'alšom texte príspevku používame na označenie Ústavnej listiny skratku Ústava ČSR. Ked’že bola prijatá ako ústavný zákon, znamená to, že ide o tzv. polylegálnu ústavu, ${ }^{1}$ teda ústavu, ktorá je tvorená viacerými právnymi predpismi v podobe ústavných zákonov. Ústava ČSR pozostávala z Preambuly, tzv. Uvozovacího zákona nasledujúceho hned' za Preambulou, ktorý sa skladal z desiatich článkov, a samotného ústavného zákona pozostávajúceho zo 6 hláv a 134 paragrafov. Signatármi (vlastnou rukou podpísanými) ústavy boli: pán prezident Československej republiky Tomáš Garrigue Masaryk, p. Tusar, p. Staňek, p. Houdek, Dr. Beneš, p. Klofáč, p. Sonntág, Dr. Heidler, p. Habrman, Dr. Winter, p. Prášek, Dr. Franke, Dr. Veselý a p. Hampl. Ústava ČSR ostala de iure platná a účinná až do prijatia tzv. Ústavy 9. mája komunistickým režimom v roku 1948, ked’ bola jej $\S 173$ ods. 1 zrušená ku dňu nadobudnutia účinnosti novej ústavy (9. júna 1948). ${ }^{2}$ Ústava prijatá v lete roku 1939 Slovenskou republikou totiž neobsahovala expressis verbis ustanovenie, ktoré by ju zrušovalo. Obsahovala len vágne ustanovenie v § 102, podl'a ktorého všetky ustanovenia právnych predpisov, ktoré sú v rozpore s touto ústavou, alebo s existenciou samostatnej Slovenskej republiky, strácajú platnost'.

Preambula ústavy z roku 1920 začínala slovami „My, národ Československý“, čo sa už vel'mi skoro ukázalo najmä v slovenskej časti republiky ako vel'mi citlivo vnímaná a neprijatá skutočnost' nezanedbatel'nou čast'ou obyvatel'stva. Toto sklamanie vychádzalo najmä z Česko-Slovenskej Dohody uzavretej v americkom Pittsburghu dňa 30. mája 1918 za prítomnosti neskoršieho prezidenta Československej republiky, pána profesora Tomáša Garrigua Masaryka. Dohoda hovorila o samostatných dvoch národoch, národe Čechov a národe Slovákov, o pomerne rozsiahlej autonómii Slovákov v spoločnej republike spočívajúcej vo vlastnej administratíve, vlastnom sneme a sústave súdov, a slovenčine ako úradnom jazyku. ${ }^{3}$ Čechoslovakizmus ako teória jednotného etnického národa bol pre väčšinu slovenskej spoločnosti nezrozumitel'ný, a v dôsledku toho neprijatel'ný. Na Slovensku sa príliš neujal, rezonoval len v časti československých politických strán, najmä u sociálnych demokratov a čiastočne agrárnikov. Na Slovensku dochádzalo medzi strnulým čechoslovakistickým postojom a rastúcim národným sebavedomím k ostrejšej názorovej konfrontácii. Súčasne nadobúdal zápas proti predstavám jednotného etnického národa a za svojbytnost' slovenského národa radikálnejšie formy, okorenené populistickým obsahom. Prejavovalo

1 Situácia, ked’ je ústavná matéria rozptýlená do viacerých právnych dokumentov ústavného charakteru, a to bez ohl'adu na to, či je alebo nie je v niektorom z nich sústredená jej podstatná a určujúca čast'. KROŠLÁK, D. a kol. Ústavné právo. Bratislava: Wolters Kluwer s. r. o., 2016, s. 42.

2 Znenie tzv. májovej Ústavy dostupné online na: http://www.upn.gov.sk/data/pdf/ustava150-48.pdf.

3 Fotografia pamätnej tabule s vyobrazením originálu textu dohody dostupná online na: https://sk.wikipedia .org/wiki/Pittsbursk\%C3\%A1_dohoda\#/media/File:Bratislava_tabula_Cesko-Slovenska_dohoda.jpg. 
sa to najmä v argumentácii l’udovej strany, ktorá prezentovala boj za autonómiu Slovenskej krajiny ako zápas so slovenskými prisluhovačmi pražskej politiky a ministerstiev v hlavnom meste republiky. V predvolebnej agitácii v rokoch 1935 a 1938 sa operovalo silnou kritikou postavenia českej komunity a jej hospodárskych pozícií na Slovensku, čo vyúst'ovalo do narastania všeobecne protičeských nálad. Verejne, napríklad v prejavoch Jozefa Tisa alebo M. Sokola v marci 1938 v Národnom zhromaždení, sa síce hlásala podpora spoločnému štátu, súčasne však nepodložené tvrdenia o „počešt’ovaní“ Slovenska, o prítomnosti státisícov Čechov a českých zamestnancov (hoci ich podl'a sčítania l'udu z roku 1930 bolo na Slovensku len 120 tisíc) neposilňovali len myšlienky československého štátneho a občianskeho povedomia. ${ }^{4}$

Tieto skutočnosti viedli k tomu, že Československá republika si do svojich základov prijatím ústavy začínajúcej slovami o Československom národe zabudovala časovanú bombu, ktorá v krízových časoch konca tridsiatych rokov naplno explodovala.

Samostatná Československá republika vznikla na území bývalej Rakúsko-Uhorskej monarchie tzv. recepčnou normou dňa 28. októbra 1918, teda zákonom o zriadení samostatného štátu československého, ktorého prvé vety zneli: „Samostatný stát československý vstoupil v život. Aby byla zachována souvislost dosavadního právního ráádu se stavem novým, aby nenastaly zmatky a upraven byl nerušený přechod k novému státnímu životu, nařizuje Národní výbor jménem československého národa jako vykonavatel státní svrchovanosti toto:..." "5

Zákon bol vyhlásený v Zbierke zákonov ako zákon č. 11/1918 Sb. Z uvedeného je zrejmé, že už takmer dva roky pred prijatím ústavy ČSR a hned' v prvom prijatom zákone republiky sa upustilo od koncepcie dvoch samostatných národov a hovorí sa o národe československom.

Odhliadnuc od toho, že prvá republika mala byt’ štátom vzdelaným, mierumilovným a pokrokovým, mala byt' najmä štátom demokratickým. Princípy demokracie a právneho štátu sú prítomné v celej ústave ČSR. Nachádzame ich už v ustanoveniach čl. II a III spomínaného Uvozovacího zákona, ked' došlo k zriadeniu Ústavného súdu skladajúceho sa zo siedmich členov. Hlavnou kompetenciou súdu bolo rozhodovat', či zákony Československej republiky a zákony snemu Podkarpatskej Rusi vyhovujú (teda sú v súlade) $\mathrm{s}$ ústavou. Úlohou ústavného súdu je ochrana ústavnosti, čo v demokracii znamená ochrana slobody, rovnosti a l’udskej dôstojnosti. Ústavné súdy majú v demokracii vel'mi delikátnu úlohu - ochránit’ základné ústavné princípy vrátane základných práv a slobôd a ústavných hodnôt proti mocným a aj proti väčšine, ktorá môže byt' reprezentovaná verejnou mienkou, a zároveň nestratit' svoju legitimitu. ${ }^{6}$

Na formovanie ústavy ČSR z roku 1920 mal výrazný vplyv rakúsky zákon o všeobecných právach štátnych občanov z roku 1867. Aj to je jeden z dôvodov, prečo bolo t’ažko predstavitel'né, že súčast'ou ústavy nebude aj úprava občianskych práv a slobôd. V dočasnej ústave prvej republiky, ktorá predchádzala ústave z roku 1920, bola tzv. recepčnou normou prevzatá úprava občianskych práv a slobôd z Rakúska.

4 FERENČUHOVÁ, B. - ZEMKO, M. a kol. V medzivojnovom Československu. Bratislava: VEDA, vydavatel'stvo Slovenskej akadémie vied, 2012, s. 447.

5 Zákon č. 11/1918 Sb. Dostupný online na: http://spcp.prf.cuni.cz/lex/11-18.htm.

6 KROŠLÁK, D. a kol., c. d., s. 33. 


\section{Dôležité články ústavy ČSR pre ochranu l'udských práv}

Podl'a $§ 1$ ods. 1 ústavy ČSR jediným zdrojom všetkej štátnej moci v republike bol l'ud. V zmysle odseku dva tohto paragrafu to bol l'ud, ktorý určenými orgánmi si sám sebe ustanovoval zákony a uvádzal ich $\mathrm{k}$ životu. Ústava obsahovala pevne zakotvený princíp, že štátne orgány nesmú prekročit’ medze $\mathrm{v}$ prípade, ak by sa mali dotknút' ústavou zaručených občianskych práv. Analógiu k tomuto ustanoveniu nachádzame aj v súčasnosti platnej a účinnej Ústave Slovenskej republiky (čl. 2 ods. 2 ústavného zákona č. 460/1992 Zb. Ústava Slovenskej republiky v znení neskorších predpisov), ked' štátne orgány môžu konat' iba na základe zákona a $\mathrm{v}$ jeho rozsahu. Konanie mimo tohto rámca nepožíva právnu ochranu. Podl'a $\S 2$ ústavy ČSR sa ČSR definovala ako demokratická republika. Išlo o mimoriadne dôležité a klúčové ustanovenia určujúce povahu a charakter prvej republiky.

V piatej hlave ústavy ČSR boli uvedené nasledovné občianske práva a slobody: rovnost', sloboda osobná a majetková, sloboda domová, sloboda tlače, zhromažd’ovacie právo, spolkové právo, petičné právo, listové tajomstvo, sloboda učenia a svedomia, sloboda prejavu, sloboda myslenia, ochrana manželstva a rodiny. Popri týchto právach a slobodách obsahovala aj brannú povinnost'.

Piata hlava ústavy ČSR niesla názov „Práva a slobody, ako i povinnosti občianske“. Hned' v jej prvom paragrafe (§ 106) a jeho odseku 1 sa ustanovuje rovnost' občanov ČSR pred zákonmi republiky, ked’že „výsady pohlavia, rodu a povolania sa neuznávajú“. Ide o jedno z klúčových ustanovení, ktoré v konečnom dôsledku reálne formovali ČSR ako republiku demokratickú a skutočne občiansku. Znamená to, že každý občan si bol rovný pre zákonom z pohl'adu ochrany jeho práv štátom, a zároveň každý občan mal rovnaké povinnosti, na ktorých výkon mal dohliadat’ štát.

V d'alšom ustanovení toho istého paragrafu, v odseku 2, sa ustanovovalo, že: „Všetci obyvatelia republiky Československej poživajú v rovnakých medziach ako štátni občania tejto republiky na jej území plnej a naprostej ochrany svojho života i svojej slobody nehl'adiac na to, akého sú pôvodu, štátnej príslušnosti, jazyka, rasy alebo náboženstva. Odchýlky od tejto zásady sú prípustné len, ked’ to medzinárodné právo dovol'uje.“

Išlo o vel'mi modernú a pokrokovú právnu úpravu. Pre porovnanie, v dnes platnej a účinnej Ústave Slovenskej republiky článok 12 odsek 2 ustanovuje, že: „Základné práva a slobody sa zaručujú na území Slovenskej republiky všetkým bez ohl’adu na pohlavie, rasu, farbu pleti, jazyk, vieru a náboženstvo, politické, či iné zmýšl’anie, národný alebo sociálny pôvod, príslušnost' k národnosti alebo etnickej skupine, majetok, rod alebo iné postavenie. Nikoho nemožno z týchto dôvodov poškodzovat', zvýhodňovat' alebo znevýhodňovat."

Z uvedeného je vel'mi jednoduché demonštrovat', že Československá republika poskytovala nielen svojim občanom, ale všetkým obyvatel’om žijúcim na jej území, modernú demokratickú právnu ochranu ich práv a slobôd, vel'mi podobnú tej dnešnej, ktorá bola prijatá takmer o 75 rokov neskôr (v roku 1992) a po skúsenosti, akou bola druhá svetová vojna. Je zrejmé, že zásada rovnosti bola v citovanom ustanovení používaná výslovne vo vzt’ahu k občanom Československej republiky. Preto bolo dôležité, že sa do ústavy dostalo aj ustanovenie, ktoré zrovnoprávnilo cudzincov, resp. iných štátnych príslušníkov žijúcich na území vtedajšieho Československa s občanmi Československa. Ústava výslovne zakazovala robit' u takýchto usadených cudzincov rozdiely z hl'adiska ich štátnej príslušnosti, jazyka, rasy alebo náboženstva. 
Štát teda chránil život a slobodu občanov a obyvatel'ov bez ohl'adu na ich pôvod, štátnu príslušnost', jazyk, rasu a náboženstvo. Je dôležité osobitne zdôraznit' pokrokovost' ústavnoprávnej úpravy tom, že kládla osobitú dôležitost' na zákaz diskriminácie na základe rasy. Musíme si totiž uvedomit' dobové reálie, o ktorých v tomto prípade hovoríme. Mám na mysli predovšetkým koniec 20. rokov a celé 30. roky 20. storočia, nástup otvorene rasistického a protižidovského štátneho režimu v Nemecku, jeho koncept rasy, celú jeho „vedeckú“ teóriu založenú na „vedeckom“ bádaní tzv. rasových antropológov a celkovú európsku politickú mikroklímu a spoločenské nálady tej doby vedúcich o pár rokov k nevídanej a nechutnej katastrofe.

Otázka osobnej slobody síce bola zaručená priamo ústavou ČSR, avšak bližšia právna úprava bola ustanovená ústavným zákonom č. 293/1920 Sb. o ochrane slobody osobnej, domovnej a tajomstva listového (podl'a $§ 107,112$ a 116 Ústavnej listiny). ${ }^{7}$ Podl’a $§ 14$ tohto zákona, zákon tvoril súčast' Ústavnej listiny. Aj na tomto prípade môžeme demonštrovat' spomínaný polylegálny charakter tejto ústavy. Nik nesmel byt' stíhaný, iba v zákonom dovolených prípadoch, a to výlučne iba súdom alebo úradom $\mathrm{k}$ tomu príslušným a v konaní zákonom upraveným. K zatknutiu osoby mohlo príst' iba na sudcom písomne odôvodnený príkaz. Do väzby bolo možné vziat' osobu najdlhšie na 48 hodín a následne musela byt' bud' prepustená alebo odovzdaná príslušnému úradu na d’alšie konanie. Vel'mi dôležitým ustanovením tohto zákona bolo ustanovenie $\S 4$, podl'a ktorého nik nesmel byt' z určitého miesta alebo územia vypovedaný a nik nesmel byt' nútený $\mathrm{k}$ tomu, aby sa $\mathrm{z}$ určitého miesta alebo územia nevzdialil. Domovú prehliadku bolo možné vykonat' iba na základe písomne odôvodneného príkazu sudcu, ktorý musel byt' doručený pri prehliadke a ak to nebolo možné, najneskôr do 24 hodín po jej vykonaní. Ak verejný funkcionár, úradník alebo zriadenec pri výkone úradnej moci alebo služby porušil ustanovenia tohto ústavného zákona, bol potrestaný za priestupok žalárom v trvaní od jedného do šest' mesiacov, a ak jednal so zlým úmyslom, bol trestaný žalárom s dobou odňatia slobody na jeden až pät rokov, pri zvlášt' prit’ažujúcich okolnostiach až do desat' rokov.

Šiesta hlava ústavy ČSR nesie názov „Ochrana menšín národných, náboženských a rasových“. Podl'a $§ 128$ odsek 1, čo je prvé ustanovenie šiestej hlavy ústavy ČSR, „Všetci štátni občania republiky Československej sú si pred zákonom plne rovní a požívajú rovnakých práv občianskych a politických nehl'adiac $\mathrm{k}$ tomu, akej sú rasy, jazyka alebo náboženstva."

To znamenalo vylúčenie akejkol’vek nerovnoprávnosti na základe kritérií ako rasa a náboženstvo, pričom takejto nerovnoprávnosti mal zabránit’ priamo štát na svojej úrovni. Bol to štát, kto prišiel so zákazom akejkol’vek diskriminácie pred zákonom na základe niektorého z týchto kritérií, čím vopred zabránil akýmkol'vek legálnym snahám o vytvorenie protižidovskej, protirómskej a inej šovinistickej legislatívy. Teda štát ako garant rovnosti občanov v ich právach a povinnostiach bez ohl'adu na náboženstvo alebo rasu.

Ďalším nemenej dôležitým ustanovením ústavy ČSR je odsek 2 toho istého paragrafu, podl'a ktorého „Rozdiel v náboženstve, viere, vyznaní a jazyku nie je žiadnemu štátnemu občanovi Československej republiky v medziach všeobecných zákonov na škodu, hlavne pokial' ide o prístup do verejnej služby, k úradom a hodnostiam, alebo pokial' ide o vykonávanie akejkol’vek živnosti a povolania.“

7 Znenie ústavného zákona dostupné online na: http://www.noveaspi.sk/products/lawText/1/1874/1/2. 
Áno, pre objektívnost' treba dodat', že v zmysle odseku 4 toho istého paragrafu ústavy ČSR mohli štátne orgány v intenciách platných alebo v budúcnosti prijatých zákonov podnikat' isté kroky, ktoré by mohli budit' zdanie obmedzovania práv garantovaných v šiestej hlave ústavy ČSR, avšak mohli tak učinit’ len z dôvodu a v rozsahu zabezpečenia verejného poriadku a bezpečnosti štátu a účinného dozoru. Takýto krok teda mal slúžit' štátu len ako akési ultima ratio $^{8}$ pre splnenie vyššieho spoločenského záujmu, ktorým bezpochyby bezpečnost' štátu je. Toto ustanovenie preto nemožno interpretovat' ako akési „zadné vrátka“ pre štátny režim na prijímanie protižidovských a protirómskych opatrení.

Z uvedeného v konečnom dôsledku vyplýva, že ČSR ako krajina, v ktorej žili mnohé národy a národnosti, l'udia rôznych náboženstiev a viery, plne rešpektovala práva a slobody svojich občanov, nerobila medzi nimi žiadne rozdiely na základe kritérií ako jazyk, pohlavie, rasa, národnost', či náboženstvo, a nedávala zákonodarcovi ani priestor, aby v budúcnosti prijal zákonodarstvo, ktoré by túto situáciu mohli akýmkol’vek spôsobom dramaticky zmenit'. Napriek tomu sa už čoskoro zmenila, a to ešte za platnosti ústavy a existencie Česko-Slovenskej republiky (tzv. 2. republiky po vyhlásený autonómie Slovenskej krajiny na jeseň 1938), ked’ autonómna vláda pristúpila k deportáciám Židov na územie odstúpené Mad’arsku po Viedenskej arbitráži.

\section{Ústava Slovenskej republiky prijatá v lete roku 1939}

Snem Slovenského štátu prijal dňa 21. júla 1939 ústavný zákon č. 185/1939 Sl. z. o ústave Slovenskej republiky, ${ }^{9}$ ktorým štát konštituoval ako republiku, hlavou ktorej je volený prezident. Napriek skutočnosti, že formálne išlo o republiku, republikánskemu, sekularizovanému a demokratickému duchu protirečil konzervatívny katolicizmus, klerikalizmus a z ústavy prýštiaci autoritatívny režim prehlbujúci sa do podoby autoritársko-klerikálneho štátneho a politického režimu, najmä vo vydaní tzv. slovenského národného socializmu, prípadne v jeho miernejšie redukovanom vydaní. ${ }^{10}$ Skladala sa z úvodného prehlásenia (a nie preambuly) a z 13 hláv obsahujúcich 103 paragrafov, pričom l'udské práva a slobody upravovala až desiata hlava s názvom „Povinnosti a práva občanov“.

Už samotný názov tejto hlavy je neštandardný, nakol'ko v prvom rade pojednáva o povinnostiach, a až následne o právach občanov. Celkovo možno napočítat' v tejto hlave ústavy sedem povinností občanov a šest' práv občanov.

Prvou povinnost'ou každého občana mužského pohlavia bolo podrobenie sa vojenskej službe alebo s ňou spojenej pracovnej činnosti a povinnost' mat' účast' pri obrane štátu. Každý občan-muž sa zároveň musel podrobit' vojenskému a polovojenskému výcviku. Na obrane štátu však participovali aj ženy, nakol'ko na obranu štátu bol podrobený každý občan bez rozdielu pohlavia za účelom pomocnej služby.

Ďalšími povinnost'ami, ktoré ústava ustanovovala občanom Slovenskej republiky, bola povinnost' duševne alebo telesne pracovat', platit' dane, dávky a poplatky na základe príslušnej zákonnej úpravy.

\footnotetext{
8 Princíp subsidiarity - obmedzenie práv až ako posledná možnost'.

9 Znenie ústavného zákona dostupné online na: https://www.upn.gov.sk/data/pdf/ustava1939.pdf.

10 BEŇA, J. Vývoj slovenského právneho poriadku. Banská Bystrica: PF UMB, 2001, s. 53.
} 
Občania boli povinní pomáhat' verejným orgánom, čiže orgánom štátu, v ich činnosti, pričom občania museli vykonat' všetky funkcie, ktoré mali na základe príslušných zákonov alebo z príkazov úradov.

Pokial' ide o právnu úpravu súkromného vlastníctva, platilo, že má sociálnu funkciu a zásada „vlastníctvo zaväzuje“, čo znamenalo, že vlastník mal za povinnost’ narábat' so svojim majetkom v záujme všeobecného dobra. Čo tým mal zákonodarca na mysli, nie je celkom zrejmé, nakol'ko ústava pojem „všeobecné dobro“ bližšie nešpecifikovala. Súkromné vlastníctvo bolo možné obmedzit’ na základe zákona, k čomu v neskoršom období aj prišlo v podobe niekol'kých zákonov snemu a v podobe vládnych nariadení (čiže v týchto prípadoch nie zákonmi, ako to vyžadovala ústava), ktoré vyvrcholili tzv. arizačným procesom, ktorý by sa dal charakterizovat’ ako štátom legalizovaná krádež podnikov a obchodov patriacich židovským spoluobčanom Slovenskej republiky.

Poslednou povinnost'ou, ktorú štát nariadil svojim občanom, bolo riadne školenie a výchova svojich detí, aby z nich vyrástli dobrí občania. V kontexte duchu a ustanovení ústavy mal zákonodarca pravdepodobne na mysli výchovu v duchu národno-krest'anskom (rímskokatolíckom), teda v duchu oficiálnej doktríny štátu.

Pokial' ide o práva občanov, každý občan mal bez rozdielu pôvodu, národnosti, náboženstva a povolania požívat' ochranu života, slobody a majetku. Na prvý pohl'ad a na danú dobu išlo o pomerne modernú právnu úpravu, avšak len do okamihu, kým sa ignorovala skutočnost', že všetky tieto práva mohli byt' obmedzené na základe len „obyčajného“ (teda nie ústavného) zákona. Právna úprava tak predpokladala ochranu života, slobody a majetku. Vzt'ahovala sa však len na občanov vojenského slovenského štátu a medzi taxatívnym výpočtom kritérií, na ktoré sa nemalo pri ochrane prihliadat' a na základe ktorých sa nemali robit' žiadne rozdiely v aplikácii ochrany, chýbala, na rozdiel od ústavy prvej Československej republiky, rasa.

Z týchto skutočností možno vyvodit' dva závery. Mnohé obmedzenia občanov predovšetkým židovskej a cigánskej (rómskej) národnosti sa diali nie na zákonnom podklade, ale na základe vládnych nariadení a nariadení s mocou zákona. Možno sa preto celkom legitímne domnievat', že mnohé právne normy, ktoré mali za následok poníženie, zdecimovanie, deportovanie a v konečnom dôsledku smrt' slovenských Židov a Cigáňov (Rómov), boli protiústavné. Ked'že však v Slovenskej republike počas celej jej existencie nebola zriadená žiadna reálne fungujúca inštitúcia, ktorá by skúmala protiústavnost' právnych predpisov, nemohli dotknutí ani teoreticky verit' v šancu, žeby sa niektorá zo štátnych inštitúcií postavila na ich obranu pre protiústavnost' týchto nariadení.

Dňa 9. septembra 1941 prijala vláda Slovenskej republiky nariadenie č. 198/1941 Sl. z. o právnom postavení Židov (tzv. Židovský kódex), ktorý Židov zbavoval mnohých práv, pričom za porušenie jeho ustanovení nariad'oval vysoké pokuty a tresty odňatia slobody. Kým výklad pojmu „Žid“ bol do vydania kódexu založený na religióznom princípe, odteraz sa tento pojem vykladal podl'a rasového princípu. To znamenalo, že kým pri religióznom výklade môžeme ešte hovorit’ o akej - takej formálno-právnej ochrane Židov pred represáliami zo strany štátu, pri rasovom výklade mal štát de facto a aj de iure rozviazané ruky. Nutne však musíme dodat', že štát a jeho orgány mali i pri religióznom výklade možnosti represálií na občanoch, nakol'ko túto ochranu požívali občania štátu len dovtedy, kým zákon neurčil inak. 
Vel'mi otázne z pohl'adu ústavnosti je obmedzovanie na právach vykonávané prostredníctvom nariadení, ked’že tieto nariadenia nemali podobu zákona, napriek tomu, že ústava výslovne ustanovovala, že spomínané občianske práva možno obmedzit' len a výlučne na základe zákona. Tento zjavný nedostatok nemožno konvalidovat' tým, že snem Slovenskej republiky zákonom č. 210/1940 Sl. z. o (zmocňovací ústavný zákon) splnomocnil vládu na vydávanie vládnych nariadení v oblasti vylúčenia Židov z hospodárskeho života a prechode ich majetku do vlastníctva krest’anov. Mimo tohto zákona bola vláda splnomocnená na vydávanie nariadení aj na základe $§ 4$ zákona č. 1/1939 Sl. z. o samostatnom Slovenskom štáte.

V ustanoveniach $\S 44$ ústavy nachádzame d'alší argument podporujúci tento právny názor. Vláda mohla vydat' nariadenie (v prípade nenahraditel'nej ujmy v hospodárskych, politických a finančných záujmov štátu) s mocou zákona s výnimkou vecí, ktoré patrili do výlučnej právomoci snemu, alebo ktoré podl’a ústavy má upravit’ zákon.

Ústava ako d'alšie občianske právo síce garantovala právo na listové tajomstvo, avšak v skutočnosti poskytovala legitímny priestor na cenzúru a kontrolu všetkých listín a písomností, ked'že v tom istom ustanovení sa nachádzala zmienka o tom, že toto právo možno na základe zákona (opät' nie ústavného) obmedzit'. Rovnaký princíp bol zvolený aj vo vzt'ahu k zhromaždovaciemu právu, právu združovat' sa a k tlačovému právu, ktoré boli garantované len v rozsahu, v akom ustanovil zákon. Nemožno preto hovorit' napríklad o slobode tlače, typickej pre demokratické krajiny. Naopak, v krajine bola zavedená silná cenzúra, v čele ktorej stál Úrad propagandy, a povolené boli len niektoré tlačoviny, ako napríklad Gardista, Slovák, Kocúr, či Katolícke noviny.

Rovnako osobná sloboda a domáci pokoj bol ústavou zaistený len v rozsahu, ktorý ustanovil zákon.

Zaujímavá je ústavná zásada, podl’a ktorej nik nesmel byt' potrestaný pre chovanie sa (správanie sa), ktoré neporušilo právoplatnú trestnú normu a ktorého trestnost’ nebola už vopred zákonom alebo zákonitou normou určená. Ústava republiky obsahovala aj čosi ako právo tretej generácie, ked' zakazovala vykorist'ovanie za prácu, pričom výška mzdy mala byt' úmerná pracovnému výkonu so zretel'om na rodinné pomery. Aby však ústava ostala verná svojmu naturelu, nepriamo zakázala akékol’vek štrajky, ked’že rušenie práce a organizovanie rušenia práce sa zakazovalo.

Z uvedeného je zrejmé, že právna úprava l'udských práv a slobôd v autoritárskej Slovenskej republike nehrala zd'aleka primárnu úlohu. Bola vyjadrená až v desiatej hlave ústavy z trinástich, obsahovala viac povinností ako práv a takmer všetky práva bolo možné kedykol'vek komfortne obmedzit' len na základe obyčajného zákona. Nehovoriac o skutočnosti, že ani túto banálnu podmienku nevedel štát v mnohých prípadoch zabezpečit', práve naopak, postupoval prostredníctvom, s najväčšou pravdepodobnost'ou, protiústavných vládnych nariadení a nariadení s mocou zákona.

Ústava priznávala práva a nariad’ovala povinnosti len občanom Slovenskej republiky, neupravovala práva a povinnosti l'udí, ktorí sa tu dlhodobo zdržiavali a žili. Počas deportácií Židov do koncentračných táborov na území dnešného Pol’ska (oficiálne išli Židia na práce do Tretej ríše) prijal slovenský snem zákon č. 68/1942 S1. z., ktorý poskytol právny základ pre deportácie Židov do zahraničia. Podl'a ustanovení $§ 3$ tohto zákona Židia vyst'ahovaní a Židia, ktorí opustili územie štátu, stratili slovenské občianstvo. Pripomíname, že ústava chránila život len občanov štátu. 
Ústava zakotvovala i slobodu vierovyznania, prejavu mienky, vedeckého bádania a umenia, avšak opät' len v medziach zákonných ustanovení, pričom niekedy sa konštatovalo, že tieto práva a slobody nesmeli porušovat' „krest’anské mravy“, ktoré tak boli povýšené na normu. Na porovnanie, ústava prvej Československej republiky používala termín ,dobré mravy“. ${ }^{11}$

\section{Ústavnoprávna úprava ochrany l'udských práv a porovnanie s ústavou z roku 1920}

V § 1 odsek 1 ústavy Slovenskej republiky (prvá hlava s názvom „Všeobecné ustanovenia“) sa Slovenská republika (SR) definuje len ako republika, a nie ako demokratická republika, ako to bolo v $§ 2$ odsek 2 ústavy Československej republiky (ČSR) z roku 1920. V Ústave SR sa nenachádza ani ustanovenie zhodné alebo aspoň podobné s ustanovením $\S 1$ odsek 1 Ústavy ČSR, v zmysle ktorého je l'ud jediným zdrojom všetkej štátnej moci v Československej republike. Naopak, podl'a úvodného prehlásenia Ústavy SR „Slovenský národ pod ochranou Boha Všemohúceho od vekov sa udržal na životnom priestore mu určenom, kde s pomocou Jeho, od ktorého pochádza všetka moc a právo, zriadil si svoj slobodný slovenský štát.“

To znamená, že pôvodom moci tu už nie je l’ud, ako to v demokratických republikách býva, ale Boh (krest’anský). Koncepcia, podl'a ktorej moc pochádza od l’udu, má pritom svoje dôsledky. Okrem iného to znamená, že vláda sa tomuto l'udu zodpovedá, pretože je ním volená (resp. formovaná z poslancov zvolených do parlamentu a pod.), a l'ud ako pôvodca všetkej moci v štáte má právo kedykol'vek túto vládu odvolat'. Naopak, ak za pôvodcu štátnej moci vyhlásime Boha, nie je potrebné ani pristúpit' k použitiu extenzívneho výkladu, aby sa mohlo príst' k záveru, že l’ud nemá žiadny účinný mechanizmus k tomu, aby spochybnil legitimitu vlády či štátnej moci ako celku, pretože človek nemá ako spochybnit' božskú autoritu. Člen vlády sa v takom prípade zodpovedá Bohu a nie l'udu tej krajiny, ktorej vláda vládne.

V Ústave SR nenájdeme žiadne ustanovenia, ktoré by sa svojim obsahom aspoň približovali k § 106 Ústavy ČSR, teda sa približovali k definícii rovnosti občanov pred zákonmi republiky. Absencia takéhoto ustanovenia následne poskytuje zákonodarcovi možnosti na prijatie takej legislatívy, ktorá vytvára „rovné a rovnejšie“ skupiny obyvatel'stva, resp. vytvára tzv. občanov druhej kategórie a stavy, čo bol aj prípad Slovenskej republiky. Pokial' totiž nezadefinujeme rovnost' pred zákonom ako ústavnoprávnu zásadu, nemôžeme sa ako občan legitímne pred orgánmi štátu dovolávat' v skutkovo a právne rovnakej (resp. vel'mi podobnej) veci rovnakého zaobchádzania. Štát v takom prípade takúto povinnost' nemá. Nehovoriac o tom, že pokial' ako občania nie sme pôvodcom moci v štáte, nemáme ani legitímny nástroj na to, aby sme si takúto rovnost' ako ústavnoprávny princíp presadili, nakol'ko takúto právomoc by mal mat' vo svojej podstate iba Boh ako pôvodca štátnej moci.

V desiatej hlave Ústavy SR s názvom „Povinnosti a práva občanov“ sa v $§ 81$ ustanovuje ústavnoprávny princíp ochrany práv občanov Slovenskej republiky. Podl’a odseku 1 tohto paragrafu: ,Všetci obyvatelia bez rozdielu pôvodu, národnosti, náboženstva a povolania požívajú ochranu života, slobody a majetku.“Ak si pozorne prečítame dikciu tejto

11 LETZ, R. Slovenské dejiny V. (1938-1945). Bratislava: Literárne informačné centrum, 2012, s. 71. 
právnej normy a porovnáme ju s príbuzným ustanovením z Ústavy ČSR (§ 106 ods. 2), prídeme $\mathrm{k}$ záveru, že nám z textu tohto ustanovenia vypadol termín „rasa“. V § 81 ods. 2 sa ustanovuje, že obmedzenie týchto práv je možné len na základe ustanovení zákonov. To znamená, že na obmedzenie práva na život postačuje „obyčajný“ zákon, čiže nie ústavný zákon, na ktorého prijatie je predsa len potrebné vyššie kvórum hlasov. Matematicky to znamená, ak sa v zmysle § 21 odsek 1 Ústavy SR nájde v sneme 14 poslancov z 80 pri minimálne tretinovej účasti (po zaokrúhlení ide o 27 poslancov), ktorá bola nevyhnutná pre uznášaniaschopnost' snemu, a tí zahlasujú za obmedzenie práva na život na základe l'ubovol'ne zvolených kritérií, ktoré si presadia do zákona, určená skupina obyvatel'ov, prípadne celé obyvatel'stvo v tom najabsurdnejšom prípade, stratí právo na osobnú slobodu alebo život. Na to všetko stačilo za istých okolností 14 poslancov snemu.

Kombináciu stavu, ked' nie je v ústave zadefinovaná rovnost' občanov pred zákonom a nie je zabezpečená ochrana občianskych práv bez ohl'adu na rasu, je možné, obzvlášt' v kontexte verejne známej rasovo motivovanej protižidovskej politiky Nemecka v 30. rokoch 20. storočia, považovat' za vel'mi nebezpečnú pre niektoré skupiny obyvatel'stva, nakol'ko poskytuje zákonodarcovi priestor na prijatie takej legislatívy, ktorá bude na základe rasových princípov potláčat' práva a slobody niektorej z týchto skupín. Nehovoriac o tom, ak ste štátom, ktorý má s krajinou, akou Nemecko v tom čase pod Hitlerovým vedením bolo, podpísanú Zmluvu o ochrannom vzt’ahu medzi Nemeckou ríšou a Slovenským štátom (Schutzvertrag, platná a účinná od 23. marca 1939), a ste nielen de facto, ale aj de iure nemeckým satelitom.

Otázka, či Slovenský snem, ktorý mal v zmysle § 6 Ústavy SR ako jediný štátny orgán v republike zákonodarnú moc prijat’ ústavu, vedel o tom, že prijatím ústavného zákona č. 185/1939 Sl. z. (Ústava SR) vytvorí priestor pre protižidovskú legislatívu, je bezpredmetná, nakol'ko je to práve snem, ktorý niesol plnú zodpovednost' za prijatie ústavy, vrátane osôb, ktoré tento ústavný zákon podpísali. Jednou z týchto osôb bol napríklad aj vtedajší predseda vlády SR (ministerský predseda), a neskorší prezident Slovenskej republiky, Jozef Tiso.

Pokial' ide o náboženskú slobodu, v jedenástej hlave Ústavy SR s názvom „Cirkve“, $\S 88$, sa ustanovuje, že „Každému sa zabezpečuje právo vol'ne plnit’ náboženské povinnosti, nakol'ko to neodporuje ustanoveniam zákona, verejnému poriadku a krest’anským mravom."

Ide o vel'mi kurióznu ochranu náboženskej slobody, ked’ štát na jednej strane garantuje túto slobodu, no jej garanciu na strane druhej podmieňuje akýmsi bližšie nikde nešpecifikovanými krest’anskými mravmi. Štátna ochrana slobodného židovského vierovyznania sa tak stáva z pohl'adu tohto ustanovenia Ústavy SR absurdná, pretože napríklad židovská vierouka nie je v súlade s krest'anskou, a preto logicky nemôžu byt' židovské mravy totožné a v súlade s krest’anskými mravmi.

V dvanástej hlave Ústavy SR s názvom „Národnostné skupiny“ sa v § 91 odsek 2 ustanovuje, že o príslušnosti občanov k národnosti sa vedie kataster. To znamená, že štát vie kedykol'vek komfortne identifikovat' príslušnost' ktoréhokol'vek občana k národnostnej skupine, t. j. príslušnost' k niektorej z menšín. Ide o vel'mi neštandardný krok, ked’že národnost' je vel'mi citlivý osobný údaj, ktorého zhromažd'ovanie zo strany orgánov štátnej moci nemusí, no môže mat' za ciel' sledovat' isté neskoršie zámery, ako sa aj neskôr v prípade Slovenskej republiky pri perzekúciách Židov ukázalo. V § 95 Ústavy SR sa zavádza 
princíp reciprocity, podl’a ktorého „Práva národnostných skupín, uvedené v ústave, platia natol'ko, nakol'ko také isté práva v skutočnosti požíva i slovenská menšina na území materského štátu príslušnej národnostnej skupiny.“

Ak vezmeme v úvahu skutočnost', že Židia v tom čase nemali na svete svoj vlastný štát, a nieto ešte štát, v ktorom by žila slovenská menšina, znamená to, že ako národnostná skupina nemali v Slovenskej republike zaručené žiadne práva v zmysle tejto dvanástej hlavy Ústavy SR. Nehovoriac o tom, že posúdit' objektívne skutočnú úroveň požívania menšinových práv v inej krajine bolo v praxi nemožné.

\section{Ústavnoprávna konformita protižidovskej legislatívy v Slovenskej republike}

Ako už bolo spomenuté, bol to snem, kto mal v zmysle Ústavy SR zákonodarnú moc, a teda právomoc prijímat' zákony, ktoré upravujú práva a povinnosti občanov Slovenskej republiky. V zmysle $\S 81$ odsek 2 Ústavy SR bolo možné obmedzit' občianske práva iba na základe zákona. $\mathrm{Z}$ uvedeného prichádzame k logickému záveru, že by to mal byt' práve snem, ktorý bude stát' za celou protižidovskou legislatívou Slovenskej republiky. Ak sa však bližšie pozrieme na jednotlivé právne normy, ktoré zo Židov (a Rómov) urobili občanov druhej kategórie, prídeme k záveru, že medzi približne desiatkami a desiatkami noriem nenájdeme takmer žiaden zákon (výnimkou je napr. ústavný zákon č. 68/1942 Sl. z. o vyst'ahovaní Židov), iba vládne nariadenia, resp. nariadenia so silou zákona. Ako je to možné, ked' ústava jasne ustanovovala, že obmedzit' občianske práva možno iba na základe zákona?

Pre odpoved' sa musíme vrátit' k vzniku štátu. Slovenský snem prijal dňa 14. marca 1939 pri vzniku samostatnej republiky Zákon o samostatnom Slovenskom štáte č. 1/1939 Sl. z., podl'a ktorého (§ 4) sa vláda splnomocnila, aby nariadením vykonávala všetko, čo je v prechodnom čase potrebné na udržiavanie poriadku a na zabezpečenie záujmov Slovenského štátu. S ohl'adom na $\S 3$ tohto zákona sa malo bez pochyby na mysli obdobie do prijatia novej ústavy (Ústavy SR z júla 1939). Hoci teda zákon hovoril o vládnych nariadeniach len tam, kde je to treba na udržanie poriadku a zabezpečenie štátnych záujmov, vláda SR do 21. júla 1939 prijala minimálne 6 nariadení, ktoré napr. vylučovali židov z verejných služieb (žid už nesmel byt' viac štátnym zamestnancom); štát dosadil do židovských podnikov dôverníkov, z ktorých sa neskôr stávali arizátori; bol vykonaný súpis židovských pol'nohospodárskych nehnutel'ností; Židia v armáde boli presunutí do oddielov, ktoré tvorili osobitné pracovné útvary slúžiace bez zbrane; Židia už nesmeli byt' vlastníkmi alebo koncesionármi verejných lekární; a mnohé d’alšie obmedzenia.

Vláda len mesiac po vzniku samostatnej republiky pristúpila vládnym nariadením k vymedzeniu pojmu Žid (č. 63/1939 Sl. z. zo dňa 18. apríla 1939). Tieto vládne nariadenia však nemali žiadnu legitimitu z pohl'adu Zákona o samostatnom Slovenskom štáte, pretože ten jasne ustanovoval, že vládne nariadenia možno prijat' len na udržanie poriadku a zabezpečenie záujmov štátu. Toto kritérium bez pochyby nespíňa ani jedno z vládnych nariadení, ktoré sa týkalo zásahu do občianskych práv slovenských občanov židovskej národnosti. Napriek tomu, tieto vládne nariadenie neboli ani po prijatí Ústavy SR zrušené (vyhlásené za neplatné), hoci v zmysle § 97 a § 98 Ústavy SR mohli byt’ na základe rozhodnutia ústavného senátu pozostávajúceho zo senátnych predsedov Najvyššieho súdu a Najvyššieho správneho súdu vyhlásené za neplatné. 
Pokial' ide o obdobie po prijatí Ústavy SR, nemožno opomenút' $§ 43$ a $\S 44$ tejto ústavy. V zmysle ustanovení $§ 43$ môže vláda vydávat' nariadenie na vykonávanie určitých zákonov a v ich medziach. V podstate ide o konštrukciu nariadení vlády SR v podmienkach dnešnej Slovenskej republiky, kde na prijatie nariadenia potrebuje mat' vláda zmocnenie v zákone ako v právnej norme vyššej právnej sily. Pri formulovaní obsahu nariadenia je čo do rozsahu limitovaná medzami zákona a medzami splnomocnenia v zákone. Podl'a $§ 44$ ods. 1 vtedajšej Ústavy SR: „Ak na zamedzenie nenahraditel’nej ujmy vážne hospodárske, finančné alebo politické záujmy štátu vyžadujú neodkladné opatrenia, vláda ich môže vydat' nariadením s mocou zákona s výnimkou vecí, ktoré patria do výlučnej právomoci snemu, alebo ktoré podl'a ústavy má upravit’ zákon.“

Ústava teda jasne ustanovovala, že na prijatie vládneho nariadenia s mocou zákona (tu treba upozornit', že ide o iný druh nariadenia, než podl'a $\S 43$, pričom tento druh nariadenia podpisoval aj prezident republiky v zmysle $\S 38$ odsek 1 písm. e) Ústavy SR) musia byt' splnené dve podmienky, a to: nejde o výlučnú právomoc snemu, a nejde o záležitost', ktorú ma podl'a ústavy upravit' zákon. Pripomíname, že podl'a $§ 81$ odsek 2 Ústavy SR bolo možné občianske práva obmedzit’ iba na základe zákona. Ked’že Ústava SR nadobudla účinnost' dňom vyhlásenia v zbierke (31. júla 1939), vláda mala jasne určené pravidlá pre prijatie akéhokol’vek nariadenia s mocou zákona po tomto dni. Ani to jej však nezabránilo pristúpit' $\mathrm{k}$ prijatiu celého radu d’alších nariadení, ktoré okliešt'ovali občianske a politické práva Židov žijúcich na Slovensku.

Vládni predstavitelia si zrejme uvedomovali tento deficit legitímnosti vládnych nariadení, a preto bol 3. septembra 1940 prijatý snemom ústavný zákon č. 210/1940 Sl. z., ktorým sa vláda splnomocňuje, aby činila opatrenia vo veciach arizácie. Snem splnomocnil vládu, aby nariadením robila všetky opatrenia, ktoré sú potrebné na vylúčenie Židov zo slovenského hospodárskeho a sociálneho života, a aby majetok Židov prešiel do vlastníctva krest’anov. Snem sa tým de facto aj de iure vzdal svojich právomocí prijímat' zákony v tejto oblasti.

Podl'a môjho názoru je však tento ústavný zákon v rozpore s už spomínaným $§ 43$ Ústavy SR, nakol'ko vláda môže vydávat' nariadenia len na vykonanie zákonov, a nie vydávat' nariadenia, ktoré nahrádzajú zákony. Vykonat' zákon neznamená prijat’ právnu úpravu, ktorá je úplne nová a nemá žiadnu oporu v zákone v zmysle, že zákon ani nepredpokladá prijatie normy v takomto konkrétnom znení. Inak povedané, vládne nariadenie nesmie íst' nad rámec zákona, ktorý prijatie vládneho nariadenia predpokladá. Ak zákonodarca ustanoví, že vláda smie prijat' nariadenia na vykonanie arizácie, ide o tak široký kontext, že v právnom štáte by takáto norma nemohla byt’ prijatá, pretože je nevykonatel'ná. Na základe čoho by sme totiž chceli posúdit', či je splnená zákonná zmocňovacia podmienka, a že nariadenie nejde svojim obsahom nad rámec zákona? Mimo tejto skutočnosti, snem sa nemôže vzdat' svojej právomoci aj s odkazom na $\S 6$ Ústavy SR, podl'a ktorého má iba on v Slovenskej republike zákonodarnú moc. Ústava nepripúšt'a v tomto prípade žiadnu výnimku a možnost' snemu delegovat' svoje právomoci na iný štátny orgán (vládu). A zároveň, ako už bolo spomenuté, Ústava SR predpokladala obmedzenie občianskych práv a slobôd len a výlučne na základe zákona. Domnievam sa preto, že ústavný zákon č. 210/1940 Sl. z. mal byt' vyhlásený ústavným senátom v zmysle $\S 97$ ods. 1 Ústavy SR za neplatný. Na základe tohto ústavného zákona vyšli odo dňa 
11. septembra 1940 do 11 . septembra 1941 všetky protižidovské právne predpisy, vrátane Židovského kódexu. ${ }^{12}$

Vláda však zjavne zastávala iný právny názor, o čom svedčí aj jej vysoká normotvorná aktivita v oblasti protižidovskej legislatívy. Okrem iných, dňa 9. septembra 1941 prijala už spomínané nariadenie o právnom postavení Židov č. 198/1941 Sl. z., v ktorého úvode sa vláda odvoláva na § 1 zákona č. 210/1940 Sl. z. ako na akt, ktorý ju splnomocnil na prijatie takéhoto nariadenia. V tomto nariadení zároveň vláda vymedzila pojem „Žid“ z hl'adiska rasového, čím sa vraciame $\mathrm{k}$ tomu, že Ústava SR neobsahovala ustanovenia o ochrane občianskych a politických práv bez ohl'adu na rasu. V kontexte uvedeného zastávame názor, že všetky nariadenia prijaté na základe tohto zákona (č. 210/1940 Sl. z.) sú absolútne nelegitímne a mali byt' vyhlásené za neplatné, prípadne mali byt' z hl'adiska právneho pozitivizmu prijaté snemom ako riadny zákon. Na margo snemu treba pre úplnost' uviest', že aj ten mal možnost' v zmysle $§ 44$ ods. 3 Ústavy SR každé jedno nariadenie vlády bud' zmenit' alebo vyjadrit' svoj nesúhlas s ním, čím by nariadenie stratilo svoju platnost'. Predseda vlády mal totiž povinnost' predložit' nariadenie súčasne s jeho vyhlásením snemu, a ten mal možnost' do troch mesiacov postupovat' v zmysle uvedeného. Autorovi príspevku nie je známa situácia, kedy by snem využil svoje oprávnenie a s niektorým nariadením, ktorého obsahom bola protižidovská právna úprava, vyjadril svoj nesúhlas.

Legislatívny chaos napokon dokresl'uje aj ústavný zákon č. 68/1942 Sl. z. o vyst’ahovaní Židov zo dňa 15. mája 1942. Zákon mal tvorit’ zákonný podklad pre deportácie slovenských Židov do zahraničia, avšak ani absencia takéhoto ústavného zákona nebránila štátnej moci začat' s deportáciami už v marci 1942, čiže bez akéhokol'vek legislatívneho oprávnenia. Odhliadnuc od tejto skutočnosti, v zmysle $\S 3$ tohto zákona, Židia vyst'ahovaní a Židia, ktorí územie štátu opustili alebo opustia, strácajú štátne občianstvo Slovenskej republiky. To znamená, že Slovenská republika im prestala poskytovat' akúkol’vek ochranu tých občianskych práv, o ktoré ich ešte nestihla svojou legislatívnou činnost'ou obrat', a zároveň im pre deportácie nemohla ani ako už svojim bývalým občanom deportovaným do cudziny zabezpečit’ ochranu života a slobody v zmysle $§ 81$ odsek 2 Ústavy SR.

\section{Základný rozdiel medzi oboma právnymi úpravami v ČSR a Slovenskej republike}

Základný a zásadný rozdiel medzi oboma spomínanými právnymi úpravami bol v tom, že kým prvá ČSR sa viac-menej úspešne dokázala aj v reálnom živote popasovat' so zabezpečovaním základných l'udských práv a slobôd nielen pre jej občanov, ale v zásade pre všetkých obyvatel'ov žijúcich na jej území, v prípade vojnovej Slovenskej republiky možno hovorit' až o akejsi ústavnoprávnej kataklizme v oblasti ochrany l'udských, občianskych a politických práv.

Najsignifikantnejšia bola táto zmena vo vzt’ahu k pauperizácii židovskej menšiny, ktorá vel'mi rýchlo devalvovala z rovnocenného obyvatel'stva na akúsi celospoločenskú socioekonomickú prít’až z pohl'adu vládnuceho autoritárskeho režimu. Najprv Židom zakázali sediet' v parku na lavičke, potom nesmeli mat' rádio, vzali im vzdelanie a prácu, až napokon mnohým vzali život. Výnimku z tohto pravidla tvorili cynické prezidentské výnimky

12 HUBENÁK, L. Rasové zákonodarstvo na Slovensku (1939-1945). Bratislava: Univerzita Komenského, Právnická fakulta, Vydavatel'ské oddelenie, 2003, s. 51. 
nevyhnutne potrebné k zabezpečeniu chodu štátu, avšak aj tie prestali platit' po potlačení SNP v roku 1944 nemeckými vojskami.

Naopak, v prvej ČSR nachádzame vel'mi zaujímavú rozhodovaciu činnost' vtedajšieho Nejvyššího soudu Československé republiky, ktorou súd vykladal jednotlivé paragrafy ústavy ČSR, nevynímajúc ustanovenia upravujúce oblast' l'udských práv.

Tak napríklad, rozhodnutím z 8. marca 1921 sp. zn. R I 316/2113 Najvyšší súd ČSR rozhodol, že $§ 109$ ústavy ČSR dovol'uje obmedzit’ vlastnícke právo zákonom, ako sa stalo aj na základe zákona prijatého dňa 27. mája 1919 pod č. 318 Sb. z. a n. Týmto zákonom došlo k zaisteniu pôdy drobných pastierov. Súd ho posúdil ako ústavne súladný na základe ustanovenia $\S 102$ ústavy ČSR.

Podl'a rozhodnutia Nejvyššího soudu ČSR zo dňa 14. 10. 1927 sp. zn. Rv I 205/27,14 v otázke aké právo použit' v spore o neplatnost' manželstva, nezáleží na tom, akej štátnej príslušnosti sú strany v čase sporu o neplatnost' manželstva, ale akej boli v čase uzavretia manželstva. Napríklad, ak právo cudzej krajiny, podl’a ktorého by bol rozhodovaný spor o neplatnost' manželstva, poznalo prekážku rôznosti náboženstiev, nesmie československý súd na ňu prihliadnut'. Svoje rozhodnutie odôvodnil s poukazom na ustanovenie $§ 124$ Ústavy ČSR, v zmysle ktorého si všetky náboženské vyznania boli rovné.

Na porovnanie, v Slovenskej republike už spomínaný ústavný senát nikdy nezasadol, hoci, ako som už naznačil, ak by si skutočne plnil svoju funkciu v zmysle ústavy SR, mohol a musel príst' $\mathrm{k}$ záverom, že nielen jednotlivé právne predpisy boli v rozpore $\mathrm{s}$ ústavou, ale vel'mi pravdepodobne celý systém pauperizujúci nielen menšinové obyvatel'stvo žijúce v Slovenskej republike bol contra legem. Ochrana práv vo vojnovej republike bola len iluzórna, v zásade nevymožitel'ná a rýdzo formálna. V žiadnom prípade sa však ani len týmito formálnymi kvalitami nemohla vyrovnat právnej úprave obsiahnutej v ústave prvej ČSR. Vel'mi výrazným príkladom sú deportácie z roku 1942, ktoré sa prvé dva mesiace diali bez akéhokol’vek právneho základu a až ex post bol prijatý ústavný zákon, ktorý deportovaných Židov zbavoval štátneho občianstva Slovenskej republiky. Podl'a § 3 ods. 2 ústavy Slovenskej republiky bolo pritom možné spôsob zániku občianstva upravit' výlučne ústavným zákonom. I to svedčí o právnom diletantizme a neschopnosti dodržiavat' čo i len to minimum práv, ktoré republika svojim občanom podl’a ústavy garantovala.

\section{Záver}

Ciel'om príspevku bolo ukázat', ako za relatívne krátke obdobie 25 rokov od prijatia vel'mi pokrokovej, humánnej a demokratickej ústavy Československej republiky v roku 1920 garantujúcej občanom štátu rovnost', pokoj, nediskrimináciu na základe rôznych menšinových typologických znakov, je možné pri istej súhre okolností zdecimovat', doslova znivočit' jednu vel'mi dôležitú čast' spoločnosti tvoriacu jej strednú vrstvu. Už v novembri 1938, teda ešte stále za platnosti a účinnosti tejto ústavy a za existencie demokratického Česko-Slovenska (tzv. 2. republiky), došlo k nel’udským deportáciám organizovanými slovenskou autonómnou vládou vedenou jej predsedom Jozefom Tisom absolútne ignorujúc vtedajšou ústavou práva garantované nielen občanom republiky, ale aj cudzincom v nej

13 Rozhodnutie Nejvyššího soudu zo dňa 8. 3. 1921 sp. zn. R I 316/21. Dostupné online na: http://www.beck -online.cz/bo/document-view.seam?documentId=njptcojsgfpxmyl2nz4v6ojvhe.

14 Rozhodnutie Nejvyššího soudu zo dňa 14. 10. 1927 sp. zn. Rv I 205/27. Dostupné online na: http://www .beck-online.cz/bo/document-view.seam?documentId=njptcojsg5pxmyl2nz4v6nzuga2q. 
žijúcim. ${ }^{15}$ Predstavte si situáciu, že len preto, že ste príliš vysoký, prinízky, zelenooký, modrooký, hnedovlasý alebo blond, Vás v mrazoch odvezú doprostred pol'a bez možnosti odtial' odíst'. Akákol'vek ústava stráca v tej chvíli zmysel, pretože štát, ktorý má garantovat' výkon práv z nej plynúcich je príčinou Vášho strádania uprostred pol’nej mizérie.

V kontexte uvedeného zastávam právny názor, v zmysle ktorého takmer celý vnútroštátny systém právnych noriem prijatých na perzekúciu (ž)Židov ${ }^{16}$ v Slovenskej republike bol s vysokou pravdepodobnost'ou nelegitímny, protiústavný a v rozpore so základnými princípmi právneho štátu. Odhliadnuc od niektorých nie najšt'astnejších formulácii uvedených v Ústave SR som presvedčený, že v prípade, ak by štátna moc dbala o striktné dodržiavanie ústavy a o jej rigorózny výklad, pričom by boli využité všetky ústavné možnosti a oprávnenia na kontrolu ústavnosti, nemohol by byt' v Slovenskej republike vyvinutý systém občanov druhej kategórie na základe vládnych nariadení a nariadení s mocou zákona, a nestihol by ich možno taký strašný osud. L'ahkost', s akou v priebehu pár mesiacov prišlo k devalvácii vel'kej časti obyvatel'stva z pohl'adu ochrany ich l'udských práv a slobôd, by mala byt' aj dnes, v časoch rozmáhajúceho sa extrémizmu, vel'mi vel'kou výstrahou.

15 Dňa 8. októbra 1938 založil Karol Sidor Hlinkovu gardu ako údernú silu Hlinkovej strany. Čo to vlastne Hlinkova garda bola? Bola vytvorená podl'a vzoru nacistickej Schutzabteilung (SA) ako úderná polovojenská jednotka a sila Hlinkovej strany. Od začiatku bola garda orientovaná na perzekúcie Židov. Dňa 3. novembra 1938 zorganizovala v reakcii na bratislavskú židovskú demonštráciu protižidovskú demonštráciu. Bola sprevádzaná napádaním Židov na uliciach a prepadávaním židovského majetku. Takáto demonštrácia sa potom opakovala každý rok v rovnaký deň. Židia boli prinútení označit’ svoje obchody, ak to už neurobili predtým gardisti. Spoločenská luza si takto vybíjala svoje primitívne pudy útokmi na Židov. Dňa 4. novembra 1938 nariadil predseda autonómnej vlády Jozef Tiso zadržat' nemajetných Židov a deportovat' ich cez nové hranice do zahraničia.

16 V právnych predpisoch sa používalo malé písmeno ,Ž“ a vel'ké písmeno „Ž “ podl'a toho, či išlo o použitie termínu žid/Žid na základe religiózneho alebo rasového princípu. Ak išlo o použitie religiózneho princípu, používalo sa na označenie židov malé písmeno „Ž“, ak o rasový princíp, používalo sa vel’ké písmeno „Ž““. 